\title{
Pemberdayaan Masyarakat Dalam Pencegahan Covid-19 Di Kecamatan Balikpapan Selatan Kota Balikpapan
}

\author{
ThalitaRifdaKhaerani $^{1 *}$, Muhammad Zaenal Arifin², Abdur Rahman ${ }^{3}$, Pajar Eka Putra \\ Ramadhan ${ }^{4}$ \\ Program Studi Administrasi Publik, Fakultas Ilmu Sosial dan Ilmu Politik, Universitas \\ Mulawarman, Samarinda, Indonesia \\ * Penulis Korespodensi : thalitarifdakhaerani@fisip.unmul.ac.id
}

\begin{abstract}
Abstrak
Kegiatan Pengabdian Kepada Masyarakat yang dilaksanakan oleh Tim Pengabdian Program Studi S1 Administrasi Publik Fisipol Universitas Mulawarman. mengacu kepada pemberdayaan masyarakat dalam pecegahan Covid-19 di Kota Balikpapan. Salah satu wilayah yang memiliki tingkat Pasien Dalam Pengawasan (PDP) dan terkonfrrmasi positif paling banyak ialah Kecamatan Balikpapan Selatan. Hal ini dilatarbelakangi oleh kurangnya tingkat kepatuhan dan keterlibatan masyarakat dalam menerapkan kebijakan Social Distancing, serta kerangnya pemahaman masayarakat terhadap protokol kesehatan dalam rangka pencegahan penyebaran Covid-19 yang mengakibatkan masih tingginya penyebaran kasus Covid-19 di Kecamatan Balikpapan Selatan, sehingga Kota Balikpapan mendapat predikat menjadi kawasan Zona Merah. Melalui kebijakan serta peraturan yang dikeluarkan oleh Pemerintah Kota Balikpapan yang tertuang pada penerbitan Surat Edaran (SE) serta PERWALI. Upaya yang dapat dilakukan Tim Pengabdian Program Studi S1 Administrasi Publik Fisipol Universitas Mulawarmanbekerjasama dengan Tim SATGAS Covid-19 Kota Balikpapan dalam melaksanakan kegiatan Pengabdian Kepada Masyarakat berupa pemberian sosialisasi kepada masyarakat serta ikut membantu penertiban pelanggar protokol kesehatan Covid-19. Sosialisasi yang dilaksanakan oleh Pemerintah Kota Balikpapan berkolaborasi dengan Tim Pengabdian Program Studi S1 Administrasi Publik Fisipol Universitas Mulawarman berupa pemberian bantuan masker serta ikut dalam penertiban pelanggaran protokol Covid-19 di salah satu titik Kecamatan Balikpapan Selatan.
\end{abstract}

Kata Kunci: Pemberdayaan Masyarakat, Pencegahan Covid-19, Sosialisasi Covid-19.

\section{PENDAHULUAN}

Kasus pandemi Corona Virus Disease(Covid-19) di Provinsi Kalimantan Timurterus mengalami penyebaran yang signifikan di hampir semua Kabupaten dan Kota. Peta penyebaran covid-19 ini terus mengalami peningkatan setiap harinya, terhitung hingga tanggal 1 Juli 2020 total kasus Covid-19 terkonfirmasi positif di Kalimantan Timur berjumlah 525 Kasus dengan jumlah sembuh berjumlah 400 kasus dan yang meninggal sebanyak 7 kasus.

Dari data diatas dapat diperoleh informasi bahwa Kota Balikpapan merupakan kota dengan peta penyebaran dan tingkat kasus covid-19 paling tinggi di Provinsi Kalimantan Timur jumlahnyadimana kasus terkonfirmasi positif berjumlah 193 orang. Hal tersebut kemudian yang berimplikasi pada tindakan pemerintah yang menjadikan Kota Balikpapan saat ini menjadi zona hitam dalam tingkat penyebaran kasus covid-19sehingga perlu diwaspadai. 
Kecamatan Balikpapan Selatan, Kota Balikpapan menjadi satu wilayahdengan total keseluruhan Pasien Dalam Pengawasan(PDP) danterkonfirmasi positif yang paling banyak sehingga menjadi salah satu kecamatandengan peta penyebaran covid-19 paling tinggi. Hal tersebut dapat dilihat dari informasiyang diperoleh dari Gugus Tugas Covid-19 Kota Balikpapan berdasarkan data Dinas Kesehatan Kota Balikpapan pada gambar 1.2 dibawah ini:

\section{Gambar 1}

Peta Persebaran Kasus Covid-19 Kota Balikpapan Per Kecamatan

Bulan Juli Tahun 2020

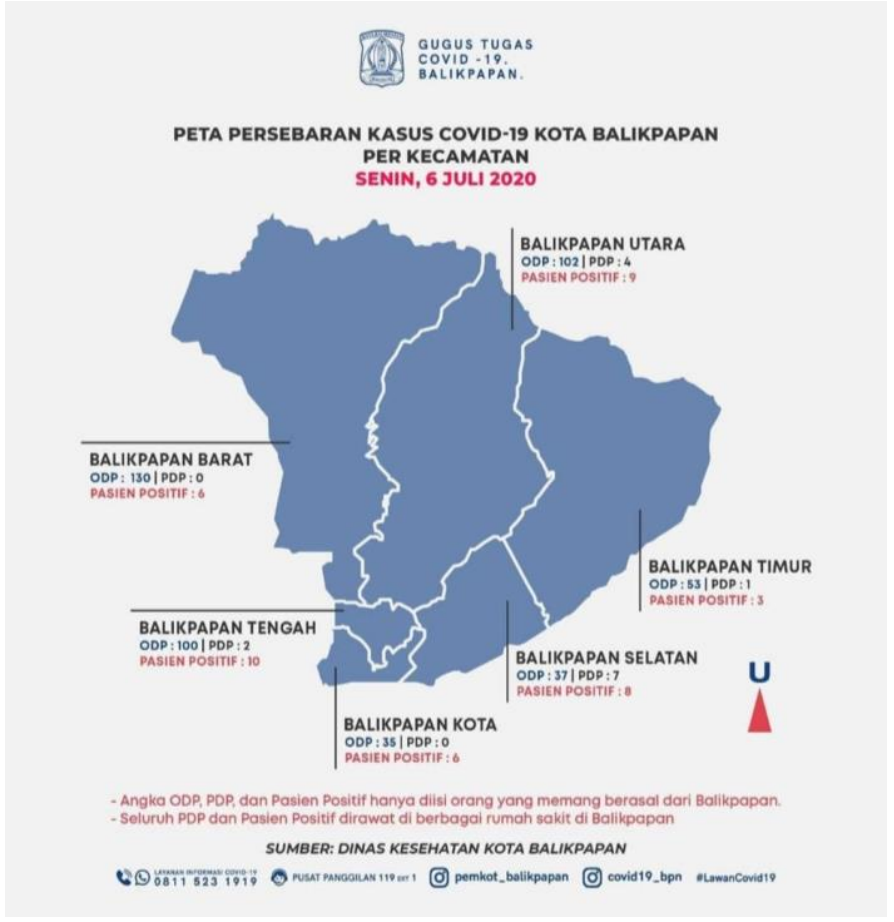

Sumber: Gugus Tugas Covid-19 Kota Balikpapan, Juli 2020

Berdasarkan data pada Gambar 1.2 tersebut dapat disimpulkan bahwa Kecamatan Balikpapan Selatan Kota Balikpapan menjadidaerah yang tingkat penyebaran kasus covid-19paling tinggi ditinjau dari totalPasien Dalam Pengawasan(PDP) berjumlah 7 orang danpasien positif sebanyak 8 orang sebagaimana ditunjukkan melalui informasi Gugus Tugas covid-19 Balikpapan per tanggal 6 Juli 2020. Adapun data persebaran kasus covid-19 Kota Balikpapan per kelurahan dapat dilihat pada gambar 1.3 sebagai berikut: 


\section{Gambar 2}

\section{Peta Persebaran Kasus Covid-19 Kota Balikpapan Per Kelurahan} Bulan Juli Tahun 2020

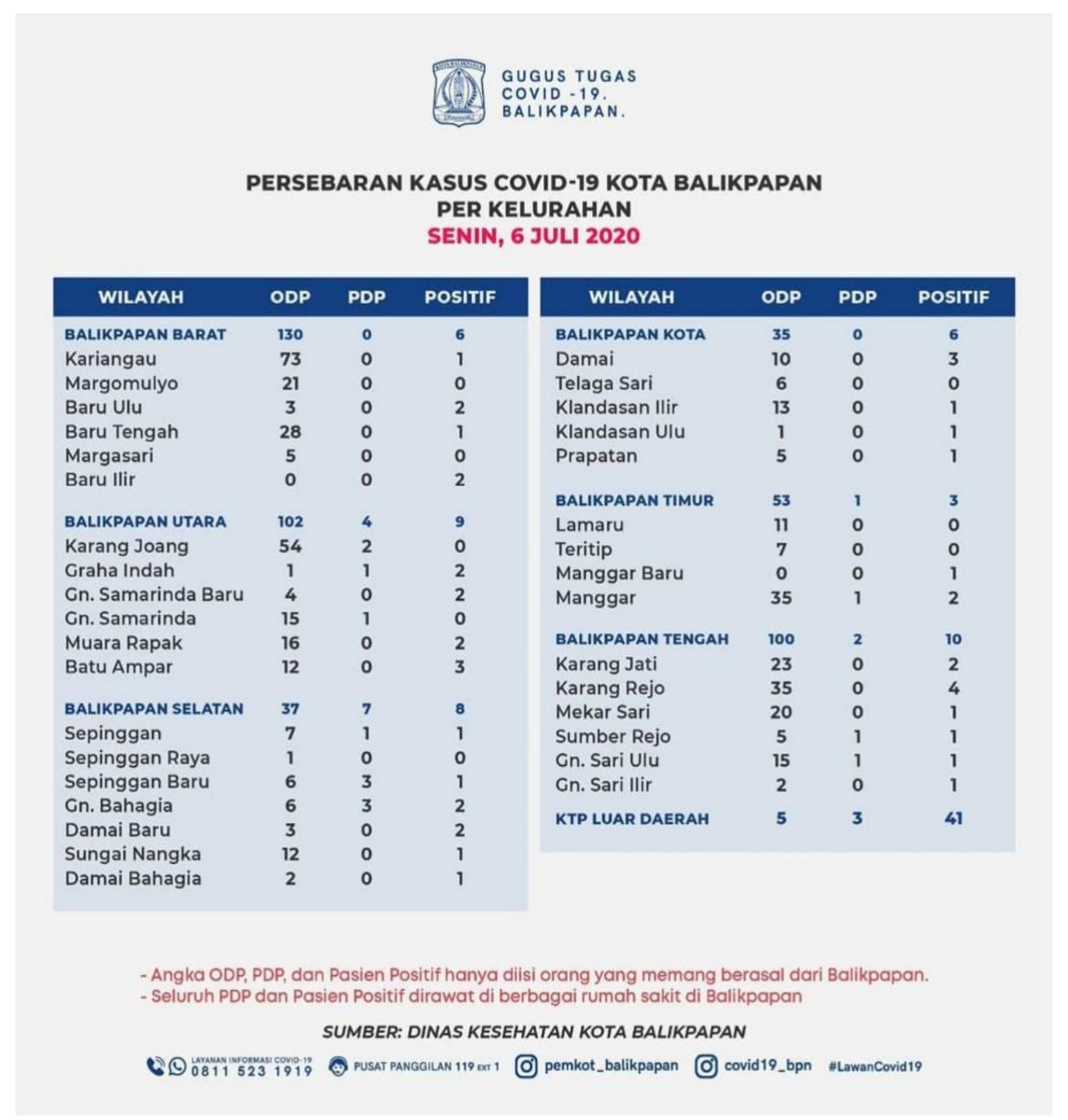

Sumber: Gugus Tugas Covid-19 Kota Balikpapan, Juli 2020

Berangkat dari situasi tersebut kemudianberimplikasi pada kondisi sosial dan kehidupan masyarakat Kecamatan Balikpapan Selatanpada masa pandemi covid-19 saat ini dimana salah satunya adalah adanya kebijakan pemerintah dalam rangka percepatan pencegahan dan penanganan covid-19 di Indonesia, yaitu dengan menerapkan kebijakan social distancing (pembatasan sosial) serta penerapan protokol kesehatan dan keamanan yang mau tidak mau juga harus dilaksanakan dan diterapkan oleh masyarakat di Kecamatan Balikpapan Selatan, Kota Balikpapan itu sendiri. 
Kecamatan Balikpapan Selatan sebagai wilayahsentral dimana padakecamatan tersebut terdapat jalur utama transportasi udara melalui Bandar Udara Internasional Sultan Aji Muhammad Sulaiman Sepinggan dan juga merupakan jalurkeluar masuk Kota Balikpapan melalui transportasi darat sehingga menjadikan daerah tersebut menjadi ramai akan hilir mudik masyarakat, baik penduduk asal di wilayah setempat maupun masyarakat pendatang. Banyaknya UMKM yang berdiri di Kecamatan Balikpapan Selatan pun turut meramaikan suasana sekitar. Namun, saat ini persoalan yang dihadapi adalah kurangnya tingkat kepatuhan dan ketertiban masyarakat dalam menerapkan kebijakan social distancingserta kurangnya pemahaman masyarakat terhadap protokol kesehatan yang seharusnya tetap diikuti dan dilaksanakan oleh masyarakat setempat dalam rangka pencegahan penyebaran covid-19 yang kemudian berimplikasi pada masih tingginya penyebaran kasus pandemi covid-19 terhitung hingga bulan Juli 2020 tersebut. Permasalahan masyarakat yang tidak paham dan disiplin dalam pencegahan covid-19 ini menjadi konsekuensi yang harus di penuhi oleh pemerintah dan pihak lainnya untuk terus melakukan upaya dalam pencegahan covid-19.

\section{METODE PELAKSANAAN}

Pada program pemberdayaan masyarakat dalam pencegahan covid-19 ini memuat beberapa langkah kegiatan pemberdayaan, yaitu:

1. Identifikasi masalah kebutuhan yang dirasakan (feel needs) dan sumber daya di Kecamatan Balikpapan Selatan, Kota Balikpapan.

2. Sosialisasi program pencegahan Covid-19 di masyarakat Kecamatan Balikpapan Selatan, Kota Balikpapan sesuai dengan protokol kesehatan.

Output: Peningkatan kesadaran masyarakat setempat melalui kegiatan edukasi.

3. Perencanaan dan penyusunan alternatif program pencegahan penyebaran covid-19 di Kecamatan Balikpapan Selatan, Kota Balikpapan.

4. Penguatan kapasitas Sumber Daya Manusia (SDM) dalam pencegahan covid-19 di Kecamatan Balikpapan Selatan, Kota Balikpapan.

Output: Bidang pendidikan dengan adanya peningkatan kapasitas SDM (aparatur keurahan/perangkat desa) setempat melalui penambahan pengetahuan terkait upaya pencegahan penularan covid-19 dan bidang sosial dengan terwujudnya masyarakat yang mampu mendukung kebijakan new normal.

5. Legalitas program atau kegiatan pemberdayaan dalam rangka pencegahan penyebaran Covid-19 di Kecamatan Balikpapan Selatan, Kota Balikpapan.

Output: terwujudnya kepatuhan masyarakat dalam menerapkan protokol kesehatan sesuai dengan regulasi yang telah ditetapkan.

6. Pendampingan/bimbingan terarah program pencegahan penyebaran covid-19 di Kecamatan Balikpapan Selatan, Kota Balikpapan sesuai jangka waktu yang telah ditentukan.

Output: dukungan edukasi secara terarah.

7. Monitoring dan evaluasi upaya pencegahan Covid-19 secara berkala sebagai bahan rujukan, masukan, dan pertimbangan bagi program pemberdayaan di tahun berikutnya. Output: keberlangsungan komunitas dan usaha.

8. Penyerahan Bantuan 


\section{HASIL DAN PEMBAHASAN}

Indikator keberhasilan pelaksanaan kegiatan Pengabdian Kepada Masyarakat ini masih berada pada tahap Penguatan (dari 5P) dimana Pengabdian Kepada Masyarakat yang dilakukan selain berupa sosialisasi dan edukasi kepada masyarakat juga terdapat upaya untuk memperkuat kapasitas SDMsetempat melalui kegiatan edukasi bagi perangkat Kelurahan Sungai Nangka, Kecamatan Balikpapan Selatan serta kegiatan razia masker si wiayah Kecamatan Balikpapan Selatan secara berkala dengan melibatkan berbagai unsur perangkat yang terlibat dan adanya upaya memberikan sanksi yang tegas bagi masyarakat pelanggar yang terjaring operasi/razia.

Di dalam penyelenggaraan Kegiatan Pengabdian Kepada Masyarakat yang dilakukan oleh Tim Pengabdian Program Studi S1 Administrasi Publik Fisipol Universitas Mulawarman ini lebih menitikberatkan kepada aspek pengabdian dari aspek sosial masyarakat, aspek pendidikan (edukasi masyarakat dan aparat), serta aspek kesehatan kesehatan terkait pencegahan penularan virus Covid-19 sebagaimana telah duiraikan dalam hasil pelaksanaan kegiatan PKM ini dengan harapan dapat memberikan manfaat khususnya dalam bidang sosial, pendidikan, dan kesehatan. Di dalam pelaksanaannya, Tim Pengabdian Program Studi S1 Administrasi Publik Fisipol Universitas Mulawarman masih akan terus melakukan monitoring dan evaluasi secara berkala sesuai dengan tahapan-tahapan pemberdayaan masyarakat sesuai yang telah diuraikan sebelumnya sehingga dapat memberikan kontribusi atau manfaat seoptimal mungkin bagi upaya pencegahan penyebaran virus covid-19, khususnya di wilayah Kecamatan Balikpapan Selatan.

Di dalam pelaksanaan kegiatan Pengabdian Kepada Masyarakat ini terdapat beberapa hal yang menjadi faktor penghambat yang dihadapi diantaranya adalah sebagai berikut:

1. Pada awal pelaksanaan Tim Pengabdian Program Studi S1 Administrasi Publik Fisipol Universitas Mulawarman mengalami hambatan dalam menentukan program yang akan diimplementasikan(sejak proses identifikasi terhadap need assessment berlangsung) pada kegiatan Pengabdian Kepada Masyarakat ini. Hal tersebut dikarenakan sulitnya menjalin komunikasi secara langsung mengingat masa pandemi yang mengharuskan segala bentuk komunikasi harus tetap mematuhi protokol kesehatan yang telah ditetapkan.

2. Belum adanya kepastian dasar hukum yang jelas terkaitkegiatanrazia jam malam (kendala administratif) yang diselenggarakan di wilayah Kecamatan Balikpapan Selatan.

3. Adanya hambatan dalam upaya penyelenggaraan forum diskusi seperti Forum Group Discussion ( $F G D$ )maupun penyampaian sosialisasi secara langsung kepada masyarakat setempat maupun kegiatan diskusi terbuka lainnya dikarenakan adanya larangan yang mengadakan kegiatan yang berpotensimengumpulkan orang banyak (berkerumun) dalam satu tempat, sehinga pelaksanaan sosialisasi yang dilakukan oleh Tim Pengabdian Program Studi S1 Administrasi Publik Fisipol Universitas Mulawarman hanya dapat dilaksanakan dengan dihadiri oleh perangkat Kelurahan Sungai Nangka, Kecamatan Balikpapan Selatan.

\section{KESEIMPULAN DAN SARAN}

Pengabdian Kepada Masyarakat yang dilakukan Program Studi S1 Administrasi Publik Fisipol Universitas Mulawarman dilakukan di tiga titik, yaitu: di Kota Balikpapan, Kecamatan Balikpapan Selatan, dan Kelurahan Sungai Nangka dengan melakukan upaya pemberdayaan 
masyarakat dengan Tema "Pencegahan Covid-19" melalui 5 (lima) tahapan pemberdayaan masyarakat, yaitu: pemungkinan, penguatan, perlindungan, penyokongan, serta pemeiharaan dengan fokus pada bidang sosial, pendidikan, dan kesehatan. Pelaksanaan kegiatan PKM ini juga dilakukan dengan memberikan bantuan berupa sejumlah masker dan flyer 4M sebagai bentuk partisipasi dengan harapan untuk mengurangi penularan Covid-19 di Kecamatan Balikpapan Selatan serta dimaksudkan untuk mengedukasi atau mengingatkan masyarakat bahwa dimanapun masyarakat berada, harus tetap menerapkan protokol kesehatan sesuai dengan yang di tetapkan oleh Pemerintah Kota Balikpapan.

Adapun yang menjadi hambatan bagi Tim Pengabdian adalah sulitnya melakukan identifikasi terhadap need assessment dalam rangka penentuan bentuk kegiatan pengabdian masyarakat akibat suitnya melakukan komunikasi secara alangsung dengan masyarakat di masa pandemi covid-19, belum adanya kepastian dasar hukum yang jelas yang dapat menunjang pelaksanaan kegiatan pengabdian, Adanya hambatan dalam upaya penyelenggaraan $F G D$, sosialisasi, maupun kegiatan diskusi terbuka lainnya dikarenakan adanya larangan yang mengadakan kegiatan yang berpotensimengumpulkan orang banyak dalam satu tempat, masih minimnya atau belum familiarnya penggunaan teknologi serupa apikasizoom meeting pada masyarakat setempat, serta keterbatasan ruang gerak dalam melakukan pengabdian kepada masyarakat sehingga tim pengabdian hanya dapat menyentuh aspek sosial, pendidikan dan kesehatan bagi masyarakat Kecamatan Balikpapan Selatan.

Berdasarkan hasil kegiatan pengabdian yang telah dilaksanakan, maka saran yang dapat diberikan oleh Tim Pengabdian Program Studi S1 Administrasi Publik Fisipol Universitas Mulawarman adalah sebagai berikut:

1. Pemerintah Kota Balikpapan hendaknya perlu meningkatkan pengawasan (monitoring) secara berkala dengan melibatkan berbagai unsur dalam penerapan protokol kesehatan disertai sanksi yang tegas di bawah payung hokum yang jelas.

2. Kecamatan Balikpapan Selatan sebaiknya melakukan pengoptimalan sosialisasi kepada masyarakat secara masif untuk meningkatkan disiplin serta kesadaran masyarakat dalam menaati protokol kesehatan Covid-19.

3. Melakukan pemberdayaan kepada masyarakat sebagai bentuk penguatan kapasitas masyarakat serta edukasi tentang penyebab, penularan, pencegahan COVID-19 dengan memanfaatkan berbagai media termasuk dukungan teknologi informasi.

\section{DAFTAR PUSTAKA}

Kementerian Kesehatan Republik Indonesia. 2020. Pedoman Pemberdayaan Masyarakat dalam Pencegahan Covid-19 di RT/RW/Desa.

Suharto, Edi. 2014. Membangun Masyarakat Memberdayakan Rakyat (Kajian Strategis Pembangunan Kesejahteraan Sosial dan Pekerjaan Sosial). Bandung: PT. RefikaEditama.

Sulistiyani, Ambar Teguh. 2004. Kemitraan dan Model-ModelPemberdayaan. Yogyakarta: Gala Media.

Badan Pusat Statistik Kota Balikpapan.2019.Kecamatan Balikpapan Dalam Angka 2019.No. Publikasi BPS :64710.1905,No. Katalog: 1102001.6471010.

Perwali No. 57 Tahun 2016, Tentang susunan Organisasi, Uraian Tugas dan Fungsi Kecamatan. 
Rifa'i, M., \& Indrihastuti, P. (2018). KOMPETENSI KARYAWAN DAMPAKNYATERHADAP KEUNGGULAN BERSAING ORGANISASI BISNIS UMKM. JURNAL EKBIS: ANALISIS, PREDIKSI DAN INFORMASI, 19(2), 11291140.

Syairozi, M., Rosyad, S., \& Pambudy, A. P. (2019). Pemberdayaan Masyarakat Sebagai Pengguna Kosmetik Alami Beribu Khasiat Hasil Produk Tani Untuk Meminimalkan Pengeluaran Masyarakat Desa Wonorejo Kecamatan Glagah KAB. LAMONGAN. Empowering: Jurnal Pengabdian Masyarakat, 3, 88-98.

Kecamatan Balikpapan Selatan Dalam Angka Tahun 2019". BPS BALIKPAPAN. balikpapankota.bps.go.id/, diakses pada tanggal 20 juli 2020, pukul 21.30 WITA "Kota Balikpapan Dalam Angka Tahun 2020". BPS BALIKPAPAN. balikpapankota.bps.go.id/, diakses pada tanggal 20 juli 2020, pukul 21.45 WITA

Peraturan Walikota Nomor 23 Tahun 2020 tentang Penerapan Disiplin dan Penegakan Hukum Protokol Kesehatan

Surat Edaran Wali Kota Balikpapan Nomor 300.2/0283/pem tanggal 22 maret 2020 tentang Penutupan dan Pengaturan Sementara Kegiatan Usaha Hiburan dan Kegiatan Usaha Surat Edaran Wali Kota Balikpapan Nomor 440/0304/pem tentang Kewajiban Menggunakan Masker Pada Saat Keluar Rumah Selama wabah virus corona tanggal 6 April 2020

Surat Edaran Wali Kota Balikpapan Nomor 100/438/Pem tanggal 4 September 2020 tentang Pemberlakuan Jam Malam di Wilayah Kota Balikpapan

http://balikpapanselatan.balikpapan.go.id/.Diakses pada hari, Selasa,21 Juli Tahun 2020,Pukul 21.00 WITA

http://dapo.dikdasmen.kemdikbud.go.id/, diakses pada tanggal 19 juli 2020, 10.30 WITA WITA. http://covid19.balikpapan.go.id/. Diakses pada Hari Kamis, 2 Juli 2020 pukul 17.00

https://covid19.go.id/edukasi/masyarakat-umum/pedoman-pemberdayaanmasyarakat-dalam-pencegahan-covid-19-di-rtrwdesa. Diakses pada Hari Jumat, 3 Juli 2020 pukul 10.00 WITA. WITA.

https://covid19.kaltimprov.go.id/. Diakses pada Hari Kamis, 2 Juli 2020 pukul 17.00

https//www.dosenpendidikan.co.id/pemberdayaan-masyarakat/. Diakses pada Hari Sabtu, 4 Juli 2020 pukul 10.00 WITA.

https://publikkaltim.com/update-balikpapan-tambah-30-kasus-baru-positif-coronaper-29-september-2020/. Diakses pada tanggal 6 Oktober 2020 Pukul 22 : 41 WITA

https://kaltim.idntimes.com/news/kaltim/anjas-pratama-1/update-covid-19-

balikpapan-samarinda-dan-bontang-per-sabtu. Diakses pada tanggal 7 Oktober 2020 Pukul 08 : 56 WITA

https://kaltim.idntimes.com/news/indonesia/riani-rahayu-2/tak-lagi merah-balikpapankini-masuk-daftar-zona-oranye-covid. Diakses pada tanggal 7 Oktober 2020 Pukul 10 : 32 WITA

https://www.instagram.com/tv/CFzVkzEBi3k/?igshid=xn5ckc5dgsmr. Diakses pada tanggal 7 Oktober 2020 Pukul $10: 36$ WITA

https://www.instagram.com/p/CFtvmyTB2e6/?igshid=1nmky93641y8c. Diakses pada tanggal 7 Oktober 2020 Pukul 13 : 36 WITA 
https://www.instagram.com/p/CFhBvS6B0Na/?igshid=1khezm7bgo7kc. Diakses pada tanggal 25 Oktober 2020 Pukul $14: 23$ WITA.

https://www.instagram.com/p/CF_xHx-Bkvo/?igshid=bch1tujqrsgw. Diakses pada tanggal 25 Oktober 2020 Pukul 15 : 02 WITA 